\title{
Distorções do espelho
}

\author{
Adriano Schwartz*
}

ASSIS, Machado de. Várias histórias. Ed. preparada por Hélio de Seixas Guimarães. São Paulo: Martins Fontes, 2004. 247 p.

. Histórias sem data. Ed. preparada por Marta de Senna. São Paulo: Martins Fontes, 2005. 254 p.

.Papéis avulsos. Ed. preparada por Ivan Teixeira. São Paulo: Martins Fontes, 2005. 338 p.

Contos fluminenses. Ed. preparada por Marta de Senna. São Paulo: Martins Fontes, 2006. 344 p.

A editora Martins Fontes vem, desde 2004, reeditando os volumes de contos de Machado de Assis. Trata-se de um trabalho precioso, que repõe em circulação na íntegra, em obras preparadas por especialistas, conjuntos de textos fundamentais. 0 projeto começou com Várias histórias, seguiu com Histórias sem data e Papéis avulsos e, recentemente, com os Contos fluminenses. Ainda falta muito para que a produção literária do escritor esteja disponível em bibliotecas e livrarias como merece $^{1}$, mas o fato é que, com estes livros, uma de suas partes mais decisivas está pelo menos acessível de modo adequado. Em vez de resenhar de forma genérica estas quatro edições, optou-se aqui por discutir brevemente um único conto, "O espelho" (incluído em Papéis avulsos). Uma das narrativas curtas mais conhecidas do autor, ela foi, surpreendemente, muito pouco estudada.

Talvez não seja exagerado pensar que, dentre estes poucos comentaristas do conto, predomine uma linhagem que extrai da obra uma suposta visão aprofundada da con-

* professor de Literatura da Escola de Artes, Ciências e Humanidades da USP. Este texto retoma, com modificações, comunicação apresentada durante congresso internacional da Abralic (Associação Brasileira de Literatura Comparada), na UERJ, em agosto de 2006.

1 Ver a respeito a introdução do mais recente livro de GLEDSON, John. Por um novo Machado de Assis. São Paulo: Companhia das Letras, 2006. 
dição do “ser humano". Veja-se, como amostra, a conclusão de um ensaio dedicado ao texto por um célebre machadiano, Augusto Meyer:

Ora, Jacobina somos nós. Botamos a farda e representamos uma paródia do nosso eu autêntico - não na vida social apenas, na vida profunda do espírito, que anda quase sempre fardado. 0 imperativo do instinto vital se encarrega de fardar o espírito para que ele não se veja no espelho tal como é na verdade. Só existem as almas exteriores, bovarizadas, mascaradas, e para elas que só navegam na sabedoria da superfície [...]. ${ }^{2}$

Outro crítico, o norte-americano Paul Dixon, afirma que o conto antecipa "em uns 30 anos o modelo fenomenológico da consciência, com sua intersubjetividade ou implicação

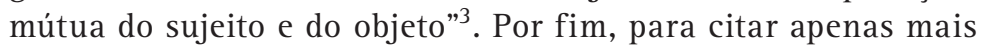
um exemplo, pode-se pensar em um estudo recente de Alfredo Bosi, 0 enigma do olhar ${ }^{4}$, no qual ele inclui a peça em uma série maior que denomina de os “contos-teoria”. De acordo com Bosi, "0 espelho" é a "matriz de uma certeza machadiana que poderia formular-se assim: só há consistência no desempenho do papel social; aquém da cena pública a alma é dúbia e veleitária."

Reforçada pela própria denominação “conto-teoria”, o que essa minúscula genealogia pretende sugerir é que essa corrente crítica talvez esteja levando demasiadamente a sério o que o texto pretenderia dizer, e deixando um pouco de lado o que ele concretamente diz: o fato de que ele está a todo instante destruindo as próprias concepções, mais propenso a distorções do que a reflexos ${ }^{5}$.

2 Ver MEYER, Augusto. 0 espelho. In: BARBOSA, João Alexandre (Org.). Textos críticos de Augusto Meyer. São Paulo: Ed. Perspectiva, 1986. p. 210.

3 Ver DIXON, Paul. Os contos de Machado de Assis: mais do que sonha a filosofia. Porto Alegre: Editora Movimento, 1992. p. 19.

4 Bosi, Alfredo. Enigma do olhar. São Paulo: Editora Ática, 1999.

$5 \mathrm{Na}$ introdução do volume de contos machadiano, o crítico Ivan Teixeira já apontava o problema, principalmente para ressaltar o lado humorístico da peça: "0 primeiro ('0 espelho') já foi bastante discutido por estudiosos, mas é provável que ainda não tenha sido inteiramente decifrado, porque sempre houve uma certa inadequação de perspectiva crítica. Normalmente, subtrai-se o conto ao conjunto humorístico e paródico de 'Papéis avulsos'”. In: ASSIS, Machado. Papéis avulsos. Ed. preparada por Ivan Teixeira. São Paulo: Martins Fontes, 2005. p. XXXVII. 
Mesmo a visada irônica, uma escapatória possível desse tipo de interpretação, pode não ser tão eficaz assim, já que vem normalmente acompanhada de um referencial imediato ao efeito irônico. Para pensar melhor sobre isso, vale a pena recorrer a uma célebre fala do conto "Teoria do medalhão", na qual o pai, em sua conversa com o filho que pretende "educar", disseca a figura:

A ironia, esse movimento do canto da boca, cheio de mistérios, inventado por algum grego da decadência, contraído por Luciano, transmitido a Swift e Voltaire, feição própria dos céticos e desabusados. ${ }^{6}$

Machado está aqui, por intermédio de sua personagem, apontando sua linhagem. Borgianamente, dir-se-ia que está escolhendo seus precursores: trata-se da tradição da sátira menipéia, tão bem estudada por Bakhtin e relacionada já diversas vezes à obra do escritor a partir do ensaio pioneiro de José Guilherme Merquior. Ao mesmo tempo, o pai dá involuntariamente uma receita para ler o próprio conto, de resto, uma das regras fundamentais da sátira menipéia: inverta tudo. Ou seja, a ironia reside no fato de que o trecho faz exatamente o que o personagem recrimina no instante mesmo em que a recriminação é feita e sendo ela própria, a ironia, o seu assunto.

Pois bem, aplicada a "0 espelho", a lei da inversão produz resultados interessantes, retirando, principalmente da segunda parte do conto, o ar circunspecto que a ela se costuma dar. Ainda assim, o texto não perde seu perfil quase filosófico: persiste uma espécie de intenção subjacente de "conhecer" o homem, mesmo que pela via negativa.

De um e de outro modo, apesar de o caminho trilhado render frutos, o esforço hermenêutico conduz, em última instância, a conclusões banais, tais como a de que essa entidade, o ser humano, "resulta" da mistura de fatores internos e externos, de que os fatores externos governam nossa existência, de que o homem está fadado a sucumbir perante o prestígio e a vaidade ou de que, ao contrário, o prestígio e a vaidade (o desejo, se se quiser alternar a terminologia) dão a esse homem força para seguir adiante...

6 ASSIS, Machado de. Papéis avulsos. Ed. preparada por Ivan Teixeira. São Paulo: Martins Fontes, 2005. p. 98. Todas as demais citações deste conto de Machado de Assis são desta edição e, a partir de agora, serão citadas apenas as páginas, entre parênteses, no próprio texto. 
A intenção aqui é colocar de lado esse aspecto "filosófico" e examinar um pouco mais detidamente o encadeamento narrativo de "0 espelho" para, quem sabe, redimensionar um pouco a questão.

Deixando para depois o comentário sobre a função desempenhada pelo conjunto título/subtítulo, podemos começar pelo primeiro parágrafo, que oscila entre um tom sarcástico e misterioso. Cito:

Quatro ou cinco cavalheiros debatiam, uma noite, várias questões de alta transcendência, sem que a disparidade dos votos trouxesse a menor alteração aos espíritos. A casa ficava no morro de Santa Teresa, a sala era pequena, alumiada a velas, cuja luz fundia-se misteriosamente com o luar que vinha de fora. Entre a cidade, com as suas agitações e aventuras, e o céu, em que as estrelas pestanejavam, através de uma atmosfera límpida e sossegada, estavam os nossos quatro ou cinco investigadores de cousas metafísicas, resolvendo amigavelmente os mais árduos problemas do universo (p. 219).

Normalmente, divide-se o conto em duas partes, que internalizam a metáfora do espelho sugerida pelo título. A primeira iria desse ponto até o momento em que Jacobina começa a contar o seu fantástico caso e é demarcada pela seguinte fala do narrador: "Eis aqui como ele começou a narração" (p. 223). Assumiria a voz, então, o segundo narrador, que permaneceria no comando até praticamente o final do texto. Tal divisão faz sentido, mas gostaria aqui de propor algo diferente. Em vez dessa repartição espelhada, sugiro uma pontuação por alguns saltos, que causam inversões e deslocamentos de sentido em maior ou menor grau - e aí surge um dos toques de gênio do autor, já que essas transições passam facilmente despercebidas. Em vez de reflexo, refrações.

Já no segundo parágrafo, somos informados que Jacobina não aceitava participar das discussões porque elas eram a "forma polida do instinto batalhador, que jaz no homem, como uma herança bestial” (p. 220). Ora, se há algo que o trecho inicial enfatiza é que as discussões não eram nada contundentes, de forma alguma evocando qualquer ancestralidade animalesca. Reitero como elas eram qualificadas: "não havia a menor alteração dos espíritos", o ambiente era profundamente harmônico, a ponto da luz das velas se confundir com a luz do luar, os "investigadores das cousas metafísicas" resolviam "amigavelmente" os "árduos problemas".

Se essa passagem torna talvez exagerada a preocupação do "provinciano, capitalista e inteligente" senhor, ela 
se justifica, contudo, logo a seguir, revertendo a inversão, quando um dos presentes "contesta" essa posição e o "desafia" a demonstrá-la se ele "fosse capaz": a agressividade latente dos termos não combina nada com a paz quase celestial anunciada no primeiro parágrafo. A provocação é respondida com uma frase, "pensando bem, talvez o senhor tenha razão" (p. 220), evidentemente ambígua. 0 que quer dizer com ela Jacobina: 1) que, sim, o senhor tem razão, preciso demonstrar concretamente a minha posição, ou 2) que, sim, o senhor tem razão, minha posição na verdade não faz tanto sentido assim...

A questão seria de extrema importância se o que viesse a seguir tivesse algo a ver com ela. 0 problema é que não tem. Toda a história das duas almas, a externa e a interna, que juntas compõem o ser humano, e todo o caso da juventude desse segundo narrador em momento algum justificam sua posição inicial de não participar de debates, o que consistiria numa réplica ao desafio, bem como não explicam uma eventual concordância, o que implicaria uma capitulação. Isso sem contar que o próprio fato de dizer que talvez o interlocutor tivesse razão já coloca Jacobina no papel a priori rejeitado de "debatedor".

A quebra de seqüência é inclusive reforçada pelo início do parágrafo seguinte: "Vai, senão quando, no meio da noite, sucedeu que este casmurro usou da palavra..." (p. 220). 0 debate encaminhou-se para a natureza da alma e, ao contrário do que afirmara o início do texto, que aqueles homens resolviam ali os "mais árduos problemas do universo", naquele momento não houve resolução alguma, a discussão tornou-se difícil, os pareceres, inconsistentes. E aí, aquele que não falava nunca foi instado a comentar a matéria, circunstância que poderia indicar que ele afinal de contas mudara mesmo sua deliberação. Só que ele aceita impondo uma condição fundamental: todos precisam ficar calados, o que repõe em pauta a ambigüidade. Então ele discorre sobre o tema, e inicia pela bombástica asserção de que o homem não tem apenas uma alma, mas duas. A idéia elevada ${ }^{7}$ é logo bastante diminuída pelos exemplos que ele escolhe para ilustrá-la: a alma exterior pode ser um fluído,

7 É curioso que este não é o único conto de Machado de Assis que poderia conter uma suposta "teoria" a respeito da alma humana. Em "As academias de Sião" (de Histórias sem data), por exemplo, é feita uma discussão bastante atual sobre "almas masculinas" e "almas femininas" à qual, no entanto, a crítica não tem dado nem de longe a mesma importância que dá a "0 espelho", talvez por conta de seu desfecho quase debochado. 
um objeto, um botão de camisa. "Metafisicamente falando", continua ele, o homem é uma "laranja", cujas duas metades se completam. Se perde uma metade, divide sua existência no meio. Perceba-se que, entre todas as frutas (para ficar no mesmo grupo "orgânico" citado) que Jacobina poderia escolher para fazer a sua comparação, optou exatamente por aquela que, espremida, praticamente desaparece, quase dizendo que, "metafisicamente falando", o homem não é nada.

Depois disso, numa estratégia narrativa que prosseguirá até o final do texto, serão apresentados exemplos e mais exemplos da presença e inter-relação das duas almas, dos quais o caso da juventude é o ponto culminante. Às vezes, eles estão distorcidos, como o que vem logo após a metáfora cítrica, quando uma citação extraída de $O$ mercador de Veneza dá entender que alma exterior de Shylock morre quando ele fica sabendo que sua filha levara seus ducados; às vezes, beiram a zombaria, como a lembrança de que para certos cavalheiros, na infância, a alma exterior era um chocalho, ou um cavalinho de pau... Desse ponto de vista, a história do alferes, momento culminante dessa pedagogia do espírito partido, funciona quase como um despiste, atraindo para si a atenção que deveria se fixar no que viera antes. Não é à toa que o primeiro narrador é praticamente expulso, retornando apenas na última linha do texto, sendo, aliás, a única figura do conto a respeitar a ordem peremptória para não interferir enquanto a narrativa fosse contada, uma vez que os outros a todo instante fazem interferências de caráter retórico que apenas reforçam o que está sendo dito.

Neste longo exemplo final, um dos participantes da conversa chega a dizer: "Custa-me a entender". Ao que Jacobina replica: "Vamos aos fatos, os fatos são tudo" (p. 226). Se os fatos são tudo, recordemo-nos brevemente deles. 0 jovem é nomeado alferes e viaja para a casa de uma tia, que, deslumbrada com a visita importante, pede que ele ali permaneça por um período. Ela o enche de mimos, obséquios e atenções, reforçando permanentemente como a patente o tornara especial e, inclusive, cedendo a ele o seu objeto mais valioso, um antigo espelho. A tia é então forçada a sair da casa pela doença de um parente, os escravos aproveitam para fugir. Sozinho, Jacobina sente falta dos cuidados e se deprime, até que tem a idéia de vestir a farda e se olhar no espelho, "terapia" que o consola e reanima.

Recontados assim, sem as elocubrações filosóficas a respeito das duas almas, os fatos só comprovam a futilidade desse narrador e imploram para que as suas idéias sejam descartadas. 
Até porque ele mesmo se encarrega de definir o lugar em que situa o pensamento especulativo, primeiro com o exemplo tautológico do filósofo grego que demonstrou o "movimento andando" e, em seguida, quando se encontra sozinho, ao descrever o ambiente que o circundava deste modo:

Corri a casa toda, a senzala, tudo, nada, ninguém, um molequinho que fosse. Galos e galinhas tão somente, um par de mulas que filosofavam a vida, sacudindo as moscas, e três bois. (p. 228).

Ou seja, que as mulas "filosofam" a vida é dito pelo mesmo homem que não podia discutir porque a discussão evocava a sua ancestralidade bestial e que naquele momento arriscava uma teoria a respeito de tão elevado assunto, filosofava. É a partir dessa premissa, "as mulas filosofam a vida", aliás, que precisa ser enquadrado o subtítulo do conto, o "esboço de uma nova teoria da alma humana”. Quanto ao título propriamente dito, vale notar o que o alferes "concretamente" enxerga quando busca a seu reflexo:

Olhei e recuei. 0 próprio vidro parecia conjurado com o resto do universo; não me estampou a figura nítida e inteira, mas vaga, esfumada, difusa, sombra da sombra. (p. 231).

$\mathrm{Na}$ imagem forte e impossível da "sombra da sombra", esse borrão, quem sabe se encontre uma dica, um momento de "verdade" de tão diminuído personagem...

Este pequeno comentário começou rememorando certa tradição interpretativa das obras de Machado de Assis. Para

8 Perceba-se que o autor utiliza a mesma expressão em um dos momentos mais fortes de outro de seus principais contos, "A causa secreta": "Garcia defronte, conseguia dominar a repugnância do espetáculo para fixar a cara do homem. Nem raiva, nem ódio; tão somente um vasto prazer, quieto e profundo, como daria a outro a audição de uma bela sonata ou a vista de uma estátua divina, alguma cousa parecida com a pura sensação estética. Pareceu-lhe, e era verdade, que Fortunato havia-o inteiramente esquecido. Isto posto não estaria fingindo, e devia ser aquilo mesmo. A chama ia morrendo, o rato podia ser que tivesse ainda um resíduo de vida, sombra de sombra; Fortunato aproveitou para cortar-lhe o focinho e pela última vez chegar a carne ao fogo. Afinal deixou cair o cadáver no prato, e arredou de si toda essa mistura de chamusco e sangue”. ASSIS, Machado de. A causa secreta. Várias histórias. Ed. preparada por Hélio de Seixas Guimarães. São Paulo: Martins Fontes, 2004. p. 102 (grifo meu). 
terminá-lo, seria o caso de relembrar outra, que nas últimas décadas vem mostrando como o escritor revela muito mais do que a princípio se imagina com suas histórias, ou seja, incorpora em sua literatura aparentemente comportada todas as contradições do Brasil do século XIX, fazendo muito do aparentemente pouco. Defende-se aqui que em "0 espelho" a equação está invertida: ele exagera, hipertrofia, transforma o excesso em ridículo para fazer pouco, o muito em quase nada, um borrão. Talvez nesse niilismo radical, que supera em tanto o seu já acomodado pessimismo, esteja afinal de contas a sua cota de preocupação filosófica com a condição humana, pois olhar o espelho nunca foi, de fato, tarefa simples. 